A. A. Kotvitska, I. O. Lobova

National University of Pharmacy

\title{
ASSESSMENT OF PUBLIC'S SATISFACTION WITH PHARMACEUTICAL CARE QUALITY
}

The investigation on the public's satisfaction with pharmaceutical care based on the analysis of questionnaire responses on pharmacy services from the patients at 27 pharmacies in Kharkiv was performed. We developed six evaluation indices for pharmacy services, and showed that the functions most sought by patients were "Attitude of pharmacy/pharmacist" and "Facilities". The objective of this study was to determine the relationship between these pharmacy functions and patient satisfaction by analyzing responses from the same questionnaire survey. Overall satisfaction score with the pharmacy was employed as the dependent variable, while the six factors derived from the 20 items evaluation scale in the questionnaire by factor analysis were used as the independent variables. As a result of analysis, it was found that four variables had a significant positive correlation with public's satisfaction, two had a significant inverse correlation, and one showed no significant correlation. These results suggest that: attitude of the pharmacists such as general attitude and specialized activities of pharmacy/pharmacist such as supplying information and explanations, and convenience of hours are not only judged to be important by patients, but also influence their satisfaction.

Key words: public's satisfaction; pharmaceutical care; pharmacy

\section{STATEMENT OF THE PROBLEM}

Patient satisfaction is a measure of how well pharmacy services meet the needs of patients in acquiring their medications. Traditionally, the purpose of pharmacies has been to make medications available. The modern pharmacy, however, also provides access points to consumers and assures drugs safety and compliance with legal and professional standards. The pharmacist also handles interpersonal relationships required at the interface of the pharmacy system and the ultimate consumer, the patient [5].

Problems in pharmacist consultation can occur when patients and pharmacists have different expectations about the pharmacist's role and pharmacy services. In developed countries, patient satisfaction is a key factor in quality assessment of the health care system, whereas in developing countries, the main quality concern has been the accessibility to health care services [7].

Increasing consumer knowledge about the contribution of the pharmacist in health care can help to make consumers more aware of how pharmacists can use their drug and disease knowledge in the improvement of care. At the same time, pharmacists in primary care face difficult choices in ba-

(๖ Kotvitska A. A., Lobova I. O., 2016 lancing the commercial and professional aspects of their profession [6]. In most countries, including Ukraine, pharmacy is run on a profit basis and is not subsidized by the state. The dual commercial/ professional role of the pharmacist is a subject of continual discussion. Pharmacists taking a business-oriented approach and placing profit before the consumer's needs will perceive giving advice and explanations on the correct use of medications as a waste of time and as not directly involving additional financial remuneration, and will therefore devote less time to patients [3].

\section{ANALYSIS OF RECENT RESEARCH AND PUBLICATIONS}

Many studies investigated ethical aspects of the activity of pharmacists and priorities of pharmacies' users in Ukraine [1, 2].

Despite the existing publications, the research studies the public's satisfaction with pharmaceutical care quality, as well as the information regarding the customers' use and views of pharmacy services lacking in our country.

\section{IDENTIFICATION OF ASPECTS OF THE PROBLEM UNSOLVED PREVIOUSLY}

A key factor in advancing pharmacy practice in pharmacies in Ukraine is the understanding of 
Table 1 (3 items), Convenient location (3 items) and Con-

\section{SOCIODEMOGRAPHIC CHARACTERISTICS AND PRESCRIPTION PROFILE OF THE RESPONDENTS}

\begin{tabular}{|l|c|c|c|}
\hline \multicolumn{1}{|c|}{ Categories } & $\begin{array}{c}\text { Males, } \\
\%(\mathrm{n})\end{array}$ & $\begin{array}{c}\text { Females, } \\
\%(\mathrm{n})\end{array}$ & Total, $\%$ \\
\hline Gender: & $26.0(39)$ & $74.0(111)$ & $100.0(150)$ \\
\hline Age, years: & & & \\
\hline Age groups (years) & & & \\
\hline $18-25$ & $7.7(3)$ & $21.6(24)$ & $18.0(27)$ \\
\hline $26-39$ & $28.2(11)$ & $18.9(21)$ & $21.3(32)$ \\
\hline $40-54$ & $20.5(8)$ & $22.5(25)$ & $22.0(33)$ \\
\hline $55-64$ & $35.9(14)$ & $30.6(34)$ & $32.0(48)$ \\
\hline$>65$ & $7.7(3)$ & $6.3(7)$ & $6.7(10)$ \\
\hline Employment: & & & \\
\hline Yes & $59.0(23)$ & $71.8(79)$ & $68.5(102)$ \\
\hline No & $41.0(16)$ & $28.2(31)$ & $31.5(47)$ \\
\hline $\begin{array}{l}\text { Number of medicines } \\
\text { in the last month: }\end{array}$ & & & \\
\hline $0-2$ & $66.7(44)$ & $33.3(22)$ & $44.0(66)$ \\
\hline $3-4$ & $41.8(23)$ & $58.2(32)$ & $36.7(55)$ \\
\hline 5 & $27.6(8)$ & $72.4(21)$ & $19.3(29)$ \\
\hline $\begin{array}{l}\text { Number of pharmacies } \\
\text { patronized last month: }\end{array}$ & & & \\
\hline 1 & $22.1(25)$ & $77.9(88)$ & $75.3(113)$ \\
\hline 2 & $35.7(10)$ & $64.3(18)$ & $18.7(28)$ \\
\hline 3 & $88.9(8)$ & $11.1(1)$ & $6.0(9)$ \\
\hline
\end{tabular}

public needs and expectations. Knowledge about public utilization and views. Pharmacy services can assist pharmacists in meeting customers' needs, in enhancing the quality of their services and in improving customer satisfaction.

Greater customer satisfaction, in turn, can be translated into greater loyalty to particular pharmacies and can facilitate the provision of pharmaceutical care through better customer-pharmacist communication.

\section{OBJECTIVE STATEMENT OF THE ARTICLE}

The objectives of our study were to assess public's attitudes towards the pharmacist's role and to determine the public's views and satisfaction with pharmaceutical care currently provided in Ukraine.

\section{PRESENTATION OF THE MAIN MATERIAL OF THE RESEARCH}

The study was carried out by using questionnaire developed for evaluation of public's satisfaction with pharmacist's role in pharmaceutical care settings. The survey consisted of 20 evaluation items grouped together related to pharmacy services and overall satisfaction with pharmacy use on the questionnaires. They are: Attitude of pharmacy/pharmacist (8 item), Availability of medications (2 items), Availability of special services (2 items), Facilities venient hours (2 items). The questions included in the questionnaire were selected to assess public's satisfaction and perspective about pharmacists' role in the health-care system.

We included the item "overall satisfaction", being located at the end of the questionnaire. This item required respondents to give an overall satisfaction rating out of a possible perfect score of 100 .

To analyze the relationship between satisfaction and pharmacy services, a multiple regression analysis was performed. Overall satisfaction with pharmacy was used as the dependent variable, and evaluation scales as the independent variables. The independent variables were determined based on the correlation coefficient between total values of item score for the pharmacy.

The characteristics of the 150 respondents who filled in the pharmacy use satisfaction score in the questionnaire were as follows (Tab. 1). In terms of gender, the group was broken into $74.0 \%$ female and $26.0 \%$ male. Both genders had maximum respondents in the age group 55-64 years, males with $35.9 \%(\mathrm{n}=14)$ and females with $30.6 \%(\mathrm{n}=34)$. Overall, $32 \%(\mathrm{n}=48)$ were $55-64$ years old. The majority of participants $(68.5 \%)$ were employed.

Fig. 1 shows the patient view of the pharmacist. $45 \%$ of respondents perceived pharmacists as health care professionals who had a good balance between health and business matters, and $28 \%$ indicated that pharmacists were more concerned with the business side of their work than with the health of their patients.

In case of any drug-related question or problem, the physician was perceived as the first person to contact by $50 \%$ of respondents; and the pharmacist, by $41 \%$. Family members and friends were cited by $9 \%$ of respondents.

Tab. 2 summarizes patient expectations about the pharmacist's role. Most of customers agreed that the pharmacist should provide them with the directions of use of medications (93\%), answer their drug-related questions $(88 \%)$, check their prescriptions for accuracy $(83 \%)$, and advise them about the treatment of minor ailments (79 \%); however, more than $70 \%$ of patients didn't expect the pharmacist to monitor their health progress and to perform any health screening.

It is interesting to note that the majority of patients desired communication skills $(100 \%$ of respondents), medication knowledge $(98.2 \%)$, honesty (87.4\%), professionalism (85.7\%), and understanding of patients' concerns $(73.2 \%)$ rather than personal aspects (friendlessness $(62.5 \%$ ) and attractive pharmacist appearance (44.8 \% )) as favorite qualities of community pharmacists (Fig. 2). Communi- 


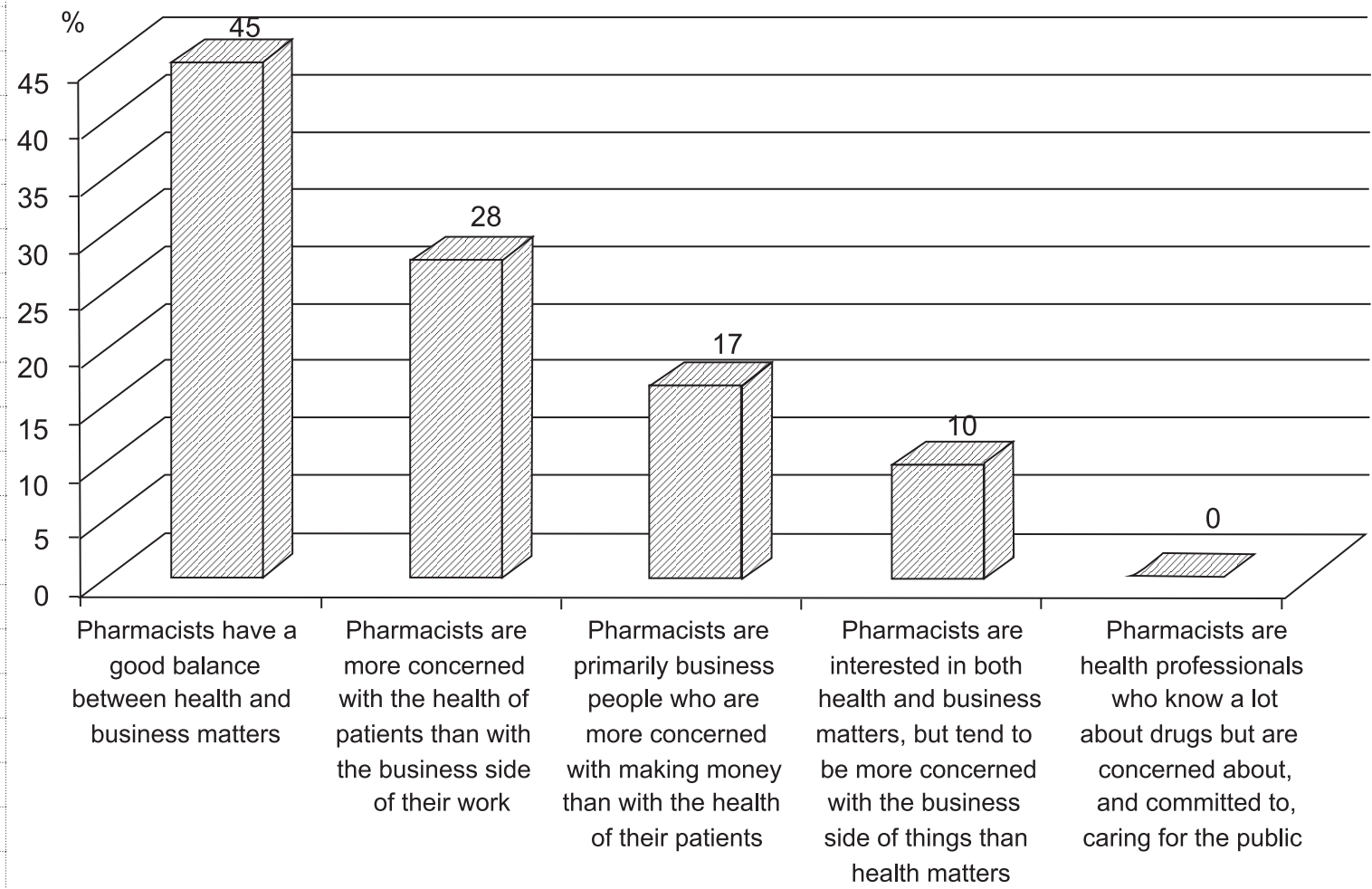

Fig. 1. Patient survey-respondent view of pharmacists

cation skills are important skills that pharmacists should master. Whether counseling patients or communicating with other health care professionals, pharmacists use their communication skills daily. Effective pharmacist communication is essential to establish an ongoing pharmacist-patient relationship, and to improve medication use by patients [4]. In addition to communication skills, to embrace the philosophy of pharmaceutical care and to ensure optimal patient outcomes, the pharmacist should have enough therapeutic experience and judgment and should be willing to address patients' needs and concerns.

The next stage of the investigation that we carried out was to analyze the relationship between satisfaction and pharmacy services. A multiple regression analysis was performed by using evaluation scores as independent variables. Hence, there

Table 2

\section{PATIENT EXPECTATIONS ABOUT THE PHARMACIST'S ROLE IN UKRAINE}

\begin{tabular}{|c|c|c|c|}
\hline Statement & \multicolumn{3}{|c|}{ Frequency ( \%) } \\
\hline I expect the community pharmacist to: & $\begin{array}{l}\text { Strongly } \\
\text { agree or } \\
\text { agree }\end{array}$ & Neutral & $\begin{array}{c}\text { Strongly } \\
\text { disagree or } \\
\text { disagree }\end{array}$ \\
\hline Counsel me about my disease & 71 & 2 & 27 \\
\hline $\begin{array}{l}\text { Counsel me about the main side effects of my medications and how to avoid } \\
\text { them and about their potential interactions with other medicines }\end{array}$ & 76 & 0 & 24 \\
\hline Counsel me about the medications' action and indication & 48 & 12 & 40 \\
\hline $\begin{array}{l}\text { Monitor my health's progress to ensure the safe and effective use of } \\
\text { medications }\end{array}$ & 23 & 10 & 67 \\
\hline $\begin{array}{l}\text { Help me in selecting a home diagnostic, an over-the-counter medication or } \\
\text { a para-pharmaceutical product }\end{array}$ & 65 & 7 & 28 \\
\hline Check my prescriptions for accuracy in terms of drug name and dose & 83 & 6 & 11 \\
\hline $\begin{array}{l}\text { Perform proper screening and monitoring for specific health conditions } \\
\text { and diseases }\end{array}$ & 26 & 9 & 65 \\
\hline
\end{tabular}




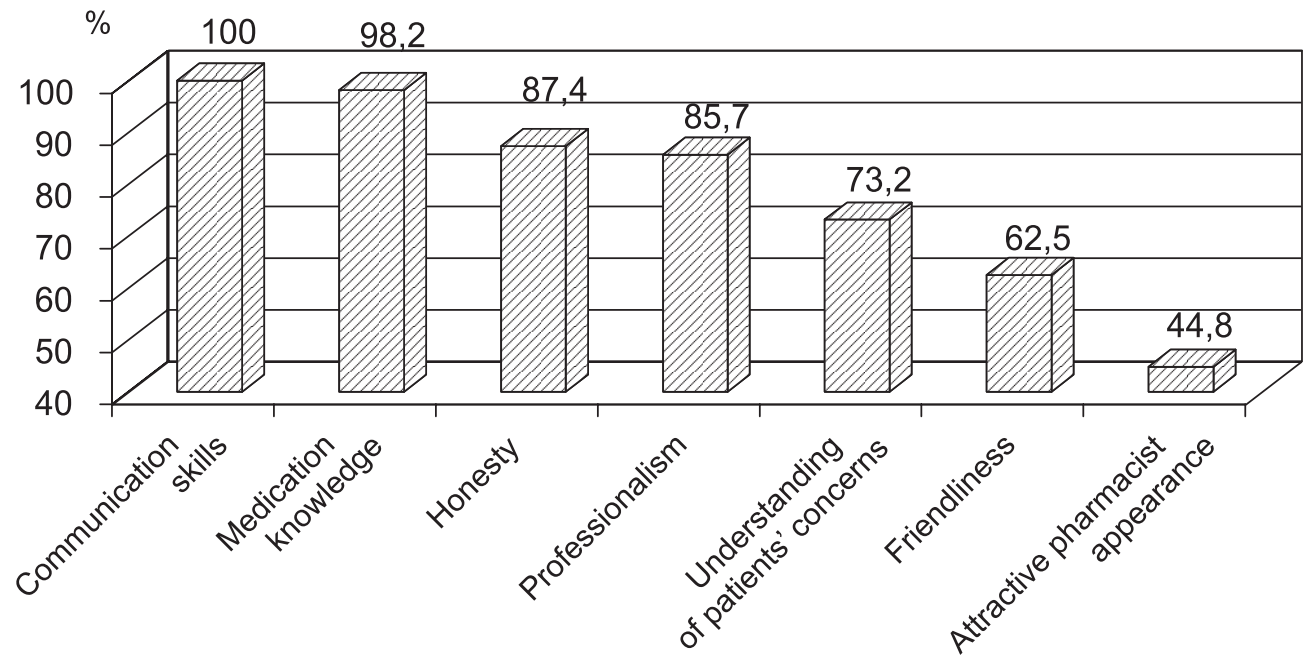

Fig. 2. Patients view of community pharmacist qualities

Table 3

CORRELATION COEFFICIENTS AND DESCRIPTIVE STATISTICS

\begin{tabular}{|l|c|c|c|c|c|c|}
\hline \multicolumn{1}{|c|}{ Evaluation scale } & 1 & 2 & 3 & 4 & 5 & 6 \\
\hline 1. Attitude of pharmacy/pharmacist & 1.000 & & & & & \\
\hline 2. Availability of medications & 0.297 & 1.000 & & & & \\
\hline 3. Availability of special services & 0.351 & 0.234 & 1.000 & & & \\
\hline 4. Facilities & 0.476 & 0.157 & 0.020 & 1.000 & & \\
\hline 5. Convenient location & 0.207 & 0.039 & 0.100 & 0.176 & 1.000 & \\
\hline 6. Convenient hours & 0.492 & 0.255 & 0.323 & 0.397 & 0.090 & 1.000 \\
\hline Evaluation score: & & & & & 7.9 \\
\hline
\end{tabular}

* Note: Evaluation scores were calculated on the basis of the following 5-point scale for each item: 5 most applicable, 4 somewhat applicable, 3 can't tell if applicable or not, 2 not very applicable, 1 not at all applicable.

was a need to determine the correlation coefficient for each scale. As shown in Tab. 3, no high correlation among analyzed factors was found. Therefore, six independent variables used in multiple regression analysis.

Tab. 4 presents the results of multiple regression analysis performed using the overall satisfaction with pharmacy use as a dependent variable, and the 6 independent variables. A significant correlation was observed for 5 variables. A significant inverse relationship was identified between "Availability of special services" and satisfaction score. The other 4 variables have a significant positive correlation, ranked as follows in declining order of influence: "Attitude of pharmacy/pharmacist", "Facilities", "Availability of medications" and "Convenient hours. Of these, "Availability of special services" had a significant inverse relationship. There was no significant relationship between "Convenient location" and satisfaction score.

The other four variables exert a positive influence on satisfaction, and the factor having the

Table 4

\section{RESULTS OF MULTIPLE REGRESSION ANALYSIS}

\begin{tabular}{|l|c|}
\hline \multicolumn{1}{|c|}{ Variables } & $\begin{array}{c}\text { Standardized } \\
\text { regression } \\
\text { coefficient }\end{array}$ \\
\hline Attitude of pharmacy/pharmacist & 0.423 \\
\hline Availability of medications & 0.067 \\
\hline Availability of special services & -0.134 \\
\hline Facilities & 0.294 \\
\hline Convenient location & -0.035 \\
\hline Convenient hours & 0.071 \\
\hline
\end{tabular}

largest standard regression coefficient was "Attitude of pharmacy/pharmacist”.

Therefore to improve pharmacy practice and to successfully implement pharmaceutical care in the pharmacies in Ukraine, efforts may be warranted to address identified issues and to promote the roles of the pharmacist in monitoring drug therapy and in serving as a public drug information resource. 


\section{CONCLUSIONS AND PROSPECTS FOR FURTHER RESEARCH}

The study of assessing public's attitudes toward the pharmacist's role and investigating the customers' views of community pharmacy suggested that the patients had good attitudes and awareness of the roles and responsibilities of the pharmacist, with the exception of monitoring patient drug therapy, performing health screening, and serving as a primary drug information resource. Several issues of concern are related to pharmacy services included: inadequate pharmacist-provided medication counseling, insufficient pharmacist-patient contact time, lack of privacy in the pharmacy, and unsatisfactory pharmacist knowledge level.

Conducted study clarified the factors determining patient satisfaction with the pharmacies they use. The results show that the functions that patients desire most of in a pharmacy are communications with the pharmacist (general attitude and specialized activities of pharmacy/pharmacist such as providing information and explanations of medications) and convenient hours.

The results of multiple regression analysis suggest that such factors as "Attitude of pharmacy/ pharmacist", "Facilities", "Availability of medications" and "Convenient hours" are key, not only as pharmacy functions that customers consciously view as important, but also as factors influencing satisfaction.

\section{REFERENCES}

1. Гриценко О. М. Етичні аспекти фармацевтичної науки і технології / О. М. Гриценко, О. М. Тернова // Фармац. журн. - 2009. № 3. - C. 19-24.

2. Мытник 3. Н. Этика на фармацевтическом рынке Украины / З. Н. Мытник, В. Г. Сердюк, К. Л. Косяченко // Здоров'я України. -2008 . - № 3. - C. 16-17.

3. Buisson J. How to make space for a consultation area in your community pharmacy? // Pharm. J. - 2009. - Vol. 275. - P. 689-691.

4. McDonough R. P. Improving communication skills of pharmacy students through effective precepting / R. P. McDonough, M. S. Bennettb // Am. J. Pharm. Educ. - 2011. - Vol. 70 (3). - P. 1-12.

5. Paddison C. A. M. Health and demographic determinants of satisfaction with pharmacy services in older adults / C. A. M. Paddison, N. A. Pachana // New Zeland J. of Psychol. 2009. - Vol. 28. - P. 133-136.

6. Tarn D. M. Physician communication when prescribing new medications / D. M. Tarn, J. Hertigae, D. A. Paterniti // Arch. Intern. Med. - 2008. - Vol. 166 (17). - P. 1855-1862.

7. Volume C. I. Pharmaceutical Care Research and Education Project; Patient Outcomes / C. I. Volume, K. B. Farris, R. Karram, C. E. Cox // J. Am. Pharmacy Assoc. - 2010. - Vol. 41. - P. 411-420. 
УДК 615.1:658.818:339.138:303.621.33

\section{А. А. Котвицкая, И. А. Лобова \\ ОЦЕНКА УДОВЛЕТВОРЕННОСТИ НАСЕЛЕНИЯ КАЧЕСТВОМ ПРЕДОСТАВЛЕНИЯ ФАРМАЦЕВТИЧЕСКОЙ ПОМОЩИ}

Проанализирован уровень удовлетворенности населения качеством предоставления фармацевтической помощи с помощью анкетирования потребителей 27 аптек г. Харькова. Нами разработано шесть показателей для оценки аптечных услуг. Проведенный анализ показал, что одним из наиболее востребованных показателей для респондентов оказалось «Отношение провизора». Цель нашего исследования заключалась в определении связи между составляющими фармацевтической помощи и удовлетворенностью потребителей. В качестве зависимой переменной использовали общую удовлетворенность от полученной фармацевтической помощи, в качестве независимых переменных были выбраны шесть факторов, оцененных по оценочной шкале. По результатам анализа установлено, что четыре показателя характеризовались значительной положительной корреляцией с уровнем удовлетворенности потребителей.

Ключевые слова: удовлетворенность потребителей; фармацевтическая помощь; аптечное учреждение

УДК 615.1:658.818:339.138:303.621.33

\section{А. А. Котвіцька, І. О. Лобова ОЦІНКА ЗАДОВОЛЕНОСТІ НАСЕЛЕННЯ ЯКІСТЮ НАДАННЯ ФАРМАЦЕВТИЧНОЇ ДОПОМОГИ}

Проаналізовано та вивчено рівень задоволеності населення якістю наданої фармацевтичної допомоги за допомогою анкетного опитування споживачів 27 аптек м. Харкова. Нами розроблено шість показників для оцінювання аптечних послуг. Проведений аналіз показав, що одним із найбільш затребуваних показників для респондентів виявилося «Ставлення провізора». Мета нашого дослідження полягала у визначенні зв'язку між складовими фармацевтичної допомоги і задоволеністю споживачів. В якості залежної змінної використовували загальну задоволеність від отриманої фармацевтичної допомоги, в якості незалежних змінних було обрано шість чинників, оцінених за оціночною шкалою. За результатами аналізу встановлено, що чотири показники характеризувалися значною позитивною кореляцією із рівнем задоволеності споживачів. Ключові слова: задоволеність споживачів; фармацевтична допомога; аптечний заклад

Адреса для листування:

61168, м. Харків, вул. Валентинівська, 4.

Тел. (0572) 67-91-81.

E-mail: socpharm@nuph.edu.ua.

Національний фармацевтичний університет
Надійшла до редакції 21.03.2016 р. 